\title{
THE SOCIAL MEDIA PHENOMENON OF SATIRE ACCOUNT @GEREJAPALSU IN THE MOVEMENT OF HOLISTIC PNEUMATOLOGY IN MISSION
}

\author{
Daniel Fajar Panuntun \\ Institut Agama Kristen Negeri Toraja \\ Jalan Poros Makale Makassar KM 11,5 Buntu Tangti, Mengkendek, \\ Kabupaten Tana Toraja, Sulawesi Selatan 91871 \\ Email: daniel_fp@stakntoraja.ac.id
}

\begin{abstract}
ABSTRAK-Globalisasi membawa kelaziman-kelaziman yang pada akhirnya diikuti di seluruh dunia. Kelaziman-kelaziman tersebut salah satunya adalah pada gaya hidup manusia. Gaya hidup manusia untuk hidup dalam kemewahan merupakan suatu gaya hidup yang sangat diminati oleh orang-orang pada di era globalisasi ini. Gaya hidup yang demikian merupakan gaya hidup konsumen kelas atas. Dampak dari hal tersebut menjadiaka setiap orang berlombalomba untuk terus hidup dalam kemewahan dengan pola hidup konsumtif dan hedon karena setiap orang ingin mendapatkan pengakuan bahwa dirinya adalah konsumen kelas atas. Gaya hidup yang demikian juga berdampak pada Gereja-gereja Tuhan pada masa kini. Beberapa Gereja seakan-akan menekankan memiliki fokus mengejar kemewahan terlihat dari tematema khotbah yang didominasi oleh khotbah-khotbah berkat. Akun satire instagram @gerejapalsu menyikapi penyimpangan-penyimpangan tersebut dengan memberikan kritik dengan gaya bahasa satire melaui postingan-postingan melalui akun instagram. Pembaharuan dengan gaya bahasa satire yang dilakukan oleh akun satire @gerejapalsu memberikan polemic tersendiri. Berdasarkan hal tersebut penelitian ini akan mencoba mengungkapkan pergerakan@gerejapalsu dan keterkaitannya dengan pergerakan pneumatology holistik. Tujuan dari penelitian ini mengungkapkan keterkaitan dari fenomena akun satire @ gerejapalsu dengan pergerakan pneumatologi holistik.

Penelitian ini menggunakan pendekatan kualitatif dengan jenis penelitian dekriptif. Pengumpulan data dilakukan dengan studi literature dan observasi non partisipan. Proses pengumpulan data dilakukan dengan: pertama, mengumpulkan data literature mengenai pnemuatologi holistik, kedua mengumpulkan data literature dan observasi non partisipan dari akun satire @gerejapalsu. Hasil dari penelitian ini menhasilkan keterkaitan antara pneumatologi holistik dan pergerakan akun satire @gerejapalsu. Penelitian ini menggambarkan keterkaitan tersebut dengan tiga keterkaitan yaitu: Pertama, Keduanya memiliki kesamaan dengan motivasi untuk terus-menerus memperbaharui Gereja Tuhan dari praktik-praktik yang menyimpang. Kedua, Keduanya memiliki kesamaan untuk terusmenerus menjaga umat Tuhan dalam panggilan Misi dan menghindarkan mereka dari doktrindoktrin yang tidak tepat. Ketiga, Keduanya memiliki kesamaan yaitu sama-sama dimarginalisasi oleh gereja-gereja mapan sebelumnya.
\end{abstract}

Kata kunci: Pneumatologi, Holistik, Satire, Instagram, @gerejapalsu

ABSTRACT-Globalization brings the norms which are eventually followed throughout the world. One of these practices is the human lifestyle. The human lifestyle to live in luxury is a lifestyle that is in high demand by people in this era of globalization. Such a lifestyle is the lifestyle of upper-class consumers. it gives an impact that everyone is competing to continue to live in luxury with a consumptive and hedon lifestyle because everyone wants to get the recognition that they are a high-class consumer. This lifestyle also affects the Churches of 
God today. Some churches seem to emphasize having a focus on the pursuit of luxury seen from the themes of the sermon which are dominated by sermons of blessing. The satire Instagram account @ gerejapalsu for counteracting these irregularities by giving criticism in the style of satire through posts via Instagram accounts. The satire Instagram account @ gerejapalsu counteracting these irregularities by giving criticism in the style of satire through posts via Instagram accounts. Renewval with satire style made by the account satire @ gerejapalsu provide a polemic. Based on that, this research will try to reveal the movement of @gerejapalsu and its relation to the holistic pneumatology movement. This study aims to reveal the link between the phenomenon of satire @gerejapalsu and the holistic pneumatology movement.

This study uses a qualitative approach to the type of descriptive research. Data collection was carried out by literature study and non-participant observation. The data collection process is done by first, collecting literature data on holistic pneumatology, secondly collecting literature data and non-participant observation from the satire account @ gerejapalsu. The results of this study are the links between holistic pneumatology and the movement of the satire account @gerejapalsu. This study illustrates that connection with three linkages: First, Both have in common with the motivation to constantly renew the Church of God of deviant practices. Second, Both have the same in continually guarding God's people in the call of Mission and avoiding them from inappropriate doctrines. Third, both have in common that they are equally marginalized by the previously established churches.

Keywords: Pneumatology, Holistic, Satire, Instagram, @gerejapalsu

\section{INTRODUCTION}

Delivering global world movement of human life to the luxury and elegance of life. Globalization occurs when new things become a norm in the world today. This custom is generally lived by all people in various worlds. The era in which everything is connected and becomes a common norm. Various factors such as communication, multinational companies, and others make each other a relatively fast occurrence. Based on this, the term globalization emerges. ${ }^{1}$ One of the common things that is happening today is lifestyle issues. Human lifestyles in the era of globalization are very much influenced by one another. The lifestyle provides a unique contribution for all human life by emphasizing a lifestyle full of luxury. The

\footnotetext{
${ }^{1}$ Herbert Nnamdi Okoye and Linda Chika Nwaigwe, "The Impact of Globalization to Business and the World Economy," International Journal of Business and Management Review 3, no. 5 (2015): 17-32, www.eajournals.org.
}

style has a global impact because so many people want to live in full luxury.

A lifestyle full of luxury is a lifestyle with consumptive and hedonic attitudes. ${ }^{2}$ This style has a global influence with the principle that it puts forward the emotions of humans. Lifestyle called the lifestyle of high-end consumers. The lifestyle emphasizes emotional value compared to functional value. This lifestyle is favored by middle and upper class consumers. ${ }^{3}$ This conception makes people today competing to fulfill their emotional desires by promoting a luxurious lifestyle. Globalization makes people have a lifestyle direction by fulfilling the needs of a luxurious life so

\footnotetext{
${ }^{2}$ T Haryono and Daniel Fajar Panuntun, "Model Gaya Hidup Nazir Sebagai Refleksi Gaya Hidup Hedon Pengkotbah Pada Zaman Milenial," Evangelikal: Jurnal Teologi Injili dan Pembinaan Warga Jemaat 3, no. 2 (2019): 174-184.

${ }^{3}$ R. Wright, Consumer Behaviour (Hampshire: Cengage learning EMA, 2006), 397.
} 
that it can be recognized by the wider community. Unfortunately, such a lifestyle occurs in the church of God and God's servants today.

The influence of lifestyle also occurs in God's servants and even God's church today. The church seems to be affected by the effects of globalization that are happening. The church is slowly beginning to follow the trends in the lifestyle of this world. The influence of lavish life that drives irregularities in the church in acts of corruption in private or in groups. ${ }^{4}$ These deviations occur because the church follows the trends of world life with its consumer phenomena and hedonism. Saputri's research states that a high level of religiosity makes the hedonism lifestyle level lower. In that study stated a negative relationship between religusitas and lifestyle hedeonism. ${ }^{5}$ Unfortunately there are churches in the present either the shepherd's personality or the church as a whole emphasizes the lifestyle of hedonism which emphasizes pleasure and blessings in this world. This can be seen from the themes of the sermons that are often raised in certain Church circles by discussing the problem of blessings. Such themes are themes favored by the parishioners in the era of globalization. This is an actual deviation but some Churches seem to allow it as a report from Eka Adhi and Ardila Saputri.

Some deviations occur because the Church does not refocus on Christ and the Bible is then influenced by the development of the world. The church

\footnotetext{
${ }^{4}$ Eka Adhi Adhi and Heru Kristanto, "Korupsi Dalam Pelayanan Gereja : Analisis Potensi Penyimpangan Dan Pengendalian Internal," Integritas 3, no. 2 (2017): 105.

5 Ardilla Saputri and Risana Rachmatan, "Religiusitas Dengan Gaya Hidup Hedonisme: Sebuah Gambaran Pada Mahasiswa Universitas Syiah Kuala,” Jurnal Psikologi 12, no. 2 (2017): 59.
}

must be able to overcome these deviations by returning to the Bible and Jesus must be the center. Holistic Bible study can be done through discipleship. Various impacts regarding discipleship include, enhance the relationship of national values ${ }^{6}$, making God's people open to share their problems ${ }^{7}$, and help everyone return to their calling ${ }^{8}$. Unfortunately, Bible study is not so desirable that in the end, the Church can fall into perversions. The church needs to be renewed in order to overcome the irregularities that occur.

Certain churches that emphasize lifestyles that look consumptive and hedonism make a polemic of its own. Various criticisms were submitted to the churches. The church should be able to pay attention by using its prophetic voice in terms of the use of misuse, deprivation of basic human rights, and the existence of a system that turns out to oppress human life. ${ }^{9}$ Unfortunately, some churches do the opposite. Certain churches build their buildings high in luxury amid social problems that occur. This is actually not a problem but some churches focus on this. "A small church is a church that is not blessed" so this motivates certain churches

\footnotetext{
${ }^{6}$ Daniel Fajar Panuntun and Eunike Paramita, "HUBUNGAN PEMBELAJARAN ALKITAB TERHADAP NILAI-NILAI ( KELOMPOK TUMBUH BERSAMA KONTEKSTUAL )," Gamaliel : Teologi dan praktika 1, no. 2 (2019): 104-115.

${ }^{7}$ T Haryono and Daniel Fajar Panuntun, "Andil Pemuridan Kontekstual Yesus Kepada Petrus Yakobus Dan Yohanes Terhadap Keterbukaan Konseling Mahasiswa Pada Masa Kini," Gamaliel : Teologi dan praktika 1, no. 1 (2019): 12-25.

${ }^{8}$ Yuliati and Kezia Yemima, "MODEL PEMURIDAN KONSELING BAGI ALUMNUS PERGURUAN TINGGI LULUSAN BARU (FRESH GRADUATE) YANG MENGINGKARI PANGGILAN PELAYANAN" 1, no. 1 (2019): 2640.

${ }^{9}$ Fibry Jati Nugroho, “Gereja Dan Kemiskinan: Diskursus Peran Gereja Di Tengah Kemiskinan.," Evangelikal : Jurnal Teologi Injili dan Pembinaan Warga Jemaat. 3, no. 1 (2019).
} 
to pursue the blessings of this world. Based on these things a polemic occurs and the church needs to get criticism or advice given by believers. Unfortunately, the criticisms and suggestions given were not accepted by these churches for various reasons.

The church as if enclosed in responding to criticism and suggestions from the people believe eventually gave birth to a revival of the account "satire" in social media. Satire style of language can be a style of language by laughing at a phenomenon that occurs with innuendo. The satire can be used to correct a phenomenon that occurs. ${ }^{10}$ Although satire is a situation in a satirical, the style of language is often used to fix something. Various studies on satire language style include: the use of satire in meme culture and satire comedy in the context of presidential elections in communication media, ${ }^{11}$ The satire style used in Ustadz Tengku Zulkarnain's Twitter account, ${ }^{12}$ The use of satire as a style of language used in memes found in social media in the current era, ${ }^{13}$ The use of satire and its analysis in the community in the victorian era, ${ }^{14}$ the use of satire in the presidential election in 2019 through an Instagram account, ${ }^{15}$ and other research. One of the

${ }^{10}$ Dewi Untari, GAYA BAHASA DALAM

MEME DI MEDIA SOSIAL. (Jakarta, 2018).

${ }^{11}$ Rendy Pahrun Wadipalapa, "Meme

Culture \& Komedi-Satire Politik: Kontestasi

Pemilihan Presiden Dalam Media Baru," Jurnal

ILMU KOMUNIKASI 12, no. 1 (2015): 1.

${ }^{12}$ Moh. Fatih Irfan, "ANALISIS GAYA

BAHASA SINDIRAN DALAM AKUN TWITTER

USTADZ TENGKU ZULKARNAIN"

(UNIVERSITAS MUHAMMADIYAH MALANG, 2019).

\footnotetext{
${ }^{13}$ Untari, GAYA BAHASA DALAM MEME DI MEDIA SOSIAL.

${ }^{14}$ Naris Eka Setyawati, “A Satire on Social Class and Gender in Victorian Society Reflected Through the Main Characters in J.M. Barrie's The Tweleve Pound Look" (Sanata Dharma, 2009).

${ }^{15}$ Ahmad Muzaki, "SATIRE POLITIK PILPRES 2019 PADA AKUN INSTAGRAM”
}

uses of satire is also done to address the Churches. Satire accounts on Instagram such as @gerejapalsu, @j_program_gerejapalsu, and several other Instagram satire accounts contribute to criticizing God's churches which have a focus on pursuing blessings and luxury.

The satire account on Instagram has an impact in the form of positive or negative responses from citizens. Based on this satire account phenomenon needs to focus on in-depth study. This satire account needs to be examined to find out whether this account has a positive impact on Christianity or not. This research will focus on the satire account movement and its relation to the movement of pneumatology holistically to renew the Church from the internal problems that are happening within it. Holistic pneumatology in mission as described in the course of the anabaptist and pentecostal-charismatic traditions

\section{PROBLEM FORMULATION}

This research focuses on two main studies, namely the phenomenon of satire accounts and the movement of pneumatology in relation to holistic mission. The formulation of the problem from this research is how does the phenomenon of satire account in relation to the holistic pneumatology movement in mission? The purpose of this study is to uncover the phenomenon of satire accounts in relation to the movement of holistic pneumatology in mission. The benefits of this research are: first, to clearly introduce the symptoms regarding satire account phenomena in relation to renewval cause of pneumatology. Second, it provides a clear explanation of the function of satire accounts in relation to pneumatology in mission. Third, it can wisely respond to the phenomenon of satire accounts in the

(UNIVERSITAS MUHAMMADIYAH MALANG, 2019). 
present so that it can understand the identity of Christianity today clearly. Fourth, provide recommendations for the movement of satire accounts in contributing to criticism of the Church of God amid disruption era.

\section{RESEARCH METHODS}

This research uses a qualitative approach. ${ }^{16}$ This approach emphasizes the search for a meaning behind the symptoms being observed. This type of research is descriptive research. ${ }^{17}$ This research is used to find a picture of a phenomenon or a picture of a particular society. This research is expected to provide clarity from the formulation of the problem so that it can be continued in further research. Data collection techniques in this study used literature study and non-participant observation. The data collection process was carried out first, collecting data related to the movement of pneumatology missions holistically based on the research journal Jody B. Fleming. Second, collecting data through literature study and non-participant observation related to Christian satire accounts on Instagram. Third, analyze the phenomenon of satirical accounts in relation to holistic pneumatology. The analysis was carried out using interactive analysis in the order of data collection, subtraction, and interpretation withdrawals. ${ }^{18}$ The results of the analysis will reveal the description of satirical phenomena in relation to holistic pneumatology.

\footnotetext{
${ }^{16}$ Stevri Indra Danik Astuti Lumintang Lumintang, Theologia Penelitian Dan Penelitian Theologis Science-Ascience Serta Metodologinya (Jakarta: Geneva Insani Indonesia, 2016).

${ }^{17}$ Kusnaka Adimihardja, Metode Penelitian Sosial : Suatu Teknik Penelitian Bidang Kesejahteraan Sosial Dan Ilmu Sosial Lainnya, ed. Jan Budhi, Edisi ke-8. (Bandung: PT Remaja Rosdakarya Offset, 2011), 34-35.

${ }^{18}$ M. B. Miles and A. M. Huberman, Qualitative Data Analysis: A Sourcebook of New Methods (California: SAGE publications, 1982).
}

\section{Holistic Pneumatology}

Pneuma can be interpreted with meanings such as wind, breath, spirit, spirit, or attitudes. This word is closely associated with spirit or air. Pneumatology is a study related to the Holy Spirit. The Bible especially Luke and the Apostles speak pneuma associated with charismata, (spiritual gifts) so that this is greatly stopped with the Holy Spirit and the various works that cover it. ${ }^{19}$ In this discussion the data on a holistic pneumatology data about the works of the Holy Spirit that have existed in this world. Holy Spirit is constantly renewing human life at all times with the whole. That is the uniqueness of the Holy Spirit as the Helper Spirit sent by Jesus.

The Holy Spirit has powerful implications for the lives of believers. Holy Spirit always works politely and in order to bring every believer into true truth. The Holy Spirit also gives inclusion to humans forever and ever. ${ }^{20}$ The Holy Spirit also directs every human life to be a witness in life. The Holy Spirit also does not discriminate based on the denominations of his Church. ${ }^{21}$ The Holy Spirit works comprehensively into human life so that it can provide a significant change for humans. The Holy Spirit is constantly trying to improve and direct human life under the correct standard is the standard of the Bible.

\footnotetext{
${ }^{19}$ Daniel Sutoyo, "Pneumatologi Lukas: Pemberdayaan Pelayanan Kristen," Jurnal Antusias 4, no. 7 (2015): 4-6, http://www.sttintheos.ac.id/ejournal/index.php/antusias/article/view/1/1.

${ }^{20}$ Frans Theodorus and Peniel C D Maiaweng, "Pneumatologi Berdasarkan Yohanes 14 : 16-17 Dan Implikasinya Bagi Kehidupan Orang Percaya," Repository Skripsi Online 1, no. 4 (2018): 270.

${ }^{21}$ Harls Evan Siahaan, "DUNAMIS ( Jurnal Teologi Dan Pendidikan Kristiani ) Karakteristik Pentakostalisme Menurut Kisah Para Rasul," DUNAMIS (Jurnal Teologi dan Pendidikan Kristiani) 2, no. 1 (2017): 12.
} 
The active role of the Holy Spirit can be chosen from the missionary journey of the Holy Spirit for this world. Amos Yong provides three criteria for pneumatology in relation to missions, namely divine presence, divine absence, and divine activity. These three things enable God's churches to present to do God's work. It also makes a manifestation of Christian hospitality that is a reflection of the hospitality of the Lord Jesus ${ }^{22}$ Although seen from the mission perspective, the presence of the Holy Spirit can be seen continually improving the spiritual life of every human being. God's mission in the world is done simultaneously by the Holy Spirit by giving direction to all the irregularities that exist in this world. Based on this the Holy Spirit continuously improves the lives of humankind.

The role of the Holy Spirit can be seen from Jody B. Fleming's research. ${ }^{23}$ The methodology of his research was using history case study. This research reveals about the research mission journey from Roman Catholic to the reform era, from the reform era to the anabaptist era and its significance with the pentecostalcharismatic mission movement in terms of pneumatology. This study provides a fairly clear picture that the Holy Spirit continually corrected the deviations committed by the Church at that time. The reform era provided a critique of Roman Catholicism at that time. At that time the teaching of reform by Luther was considered heresy and many of his followers suffered persecution. The next phase is the stagnation of the reform era so that anabaptist flow emerges. Anabaptists develop a theology that is considered

\footnotetext{
${ }^{22}$ Junifrius Gultom, "PNEUMATOLOGI AMOS YONG DAN REFLEKSI MISIOLOGI (Perspektif Pentakosta/Kharismatik Indonesia)," Jurnal Antusias 2, no. 4 (2013).

${ }^{23}$ Jody B. Fleming, "Holistic Pneumatology in Mission," Anabaptist Witness 1 (2017): 11-28.
}

heretical by the understanding of the Lutheran and reform so that the same thing also happened in the Anabaptist are experiencing persecution. That is because the teachings of anabaptists are considered to be deviant teachings, although anabaptists were born when Luther and Reform were busy taking care of affairs to establish church organization, liturgy, and the church system so that they forgot to mission out. Finally, a pentecostalcharismatic movement as a movement that claims to be led by the Holy Spirit. This movement's mission when the world was hit by sluggishness due to the growing modernism and idealism. The beginning of this teaching also states that this school is a false sect and is not under Christian teachings. ${ }^{24}$

Fleming's research reveals the results of his first research: both the teachings of anabaptists and Pentecostalcharismatics are longing to make a better Christian faith relationship. The teaching is teaching to give a renewal to the Church at that time. Second, Anabaptists and Pentecostals also have a very strong mission call for the survival of God's Kingdom on this earth. Third, both traditions also give heart to ecumenical involvement and emphasize the transformation of life. Fourth, they are equally marginalized because of the new teachings they bring and suffer persecution. ${ }^{25}$ The results of the study revealed that the Holy Spirit has a role to continually renew the teachings that are developing in the Church. The Holy Spirit has a reason to continually renew the Church of God as a form of divine inclusion in God's Churches in this world. This shows that if there is stagnation in the church, the Holy Spirit does not lack ways to continue to renew and encourage the Church to faithfully mission.

\footnotetext{
24 Ibid.

${ }^{25}$ Ibid., 19-22.
} 
The emphasis in this research is one of marginalization directed at the anabaptists and pentecostal-charismatics in relation to the pneumatology of Holistic missions. The early Anabaptists and the early Pentecostal-charismatic Movement experienced marginalization by earlier established Churches. Mockery, insults, and persecution were given to these two traditions during the early movements. This has encouraged them to isolate themselves from these old corrupt churches. The result is an anti-ecumenical attitude between the Churches. ${ }^{26}$ The emphasis in this research is one of marginalization directed at the anabaptists and pentecostal-charismatics in relation to the pneumatology of Holistic missions. The early Anabaptists and the early Pentecostal-charismatic Movement experienced marginalization by earlier established Churches. Mockery, insults, and persecution were given to these two traditions during the early movements. This has encouraged them to isolate themselves from these old corrupt churches. The result is an anti-ecumenical attitude between the Churches.

\section{Satire Account @gerejapalsu}

Satire is a style of language used to insinuate a situation or symptoms. A good satire style is a style of language that is self-correcting but has a purpose or goal as an improvement of a symptom or a situation. $^{27}$ The satire @gerejapalsu account explains that satire is a form of education. Satire can help every community to be increasingly interested in a subject matter and then spur itself to continue to develop that knowledge. Satire is different from sarcasm. Sarcasm preaches by labeling the news to someone and then, in the end, can bring the person

\footnotetext{
${ }^{26}$ Ibid., 19.

${ }^{27}$ Untari, GAYA BAHASA DALAM MEME DI MEDIA SOSIAL.
}

down with the insults given. Sarcasm has a tendency to turn off someone's character but satire encourage people to continue to learn and realize there is something wrong against him in a language satire. ${ }^{28}$ Based on the explanation, satire language is better used to educate the general public to know things that deviate by using satire language. Even though Satire is loaded with education, it will be popular because there is also a syndicated language which is sometimes a language of humor that can be enjoyed by the general public.

Some satire accounts on Instagram against Christianity in the current era include @gerejapalsu, @jemaat_gerejapalsu, and several other satire Christian accounts that are trending on Instagram. The account is an account for the community itself because it contains content that is educational but with satirical language, especially for Christians. The @ gerejapalsu account has several rules: first, followers will be removed if they are non-Christians. Second: if a follower's citizens write rude words that are inappropriate in the comments column then they will be given a sanction in the form of a block or unfollow. Third, it will be removed if citizens do not understand the meaning of "satire" and end up getting lost with this account. Fourth, it will be removed if citizens respond to posts from satire accounts with lengthy debates and stupid arguments that ultimately provoke others to say harshly.. ${ }^{29}$ The satire @ gerejapalsu account has strict rules for its followers. This rule is made so that citizens can wisely understand the meaning of the satire

${ }^{28} @$ gerejapalsu, “About Us," accessed January 22, 2020,

https://www.instagram.com/stories/highlights/1791 4047550292920/.

$29 @$ @gerejapalsu, “Rules," last modified 2019, accessed January 22, 2020, https://www.instagram.com/stories/highlights/1802 6363224126762/. 
language style created by this account. @ gerejapalsu has 1,280 posts, 61.3 K followers, and has other social media accounts namely twitter and youtube. To make sense of the satire language style, there is a non-satire account that provides an explanation namely the @ bukangerejapalsu account. ${ }^{30}$

The purpose of the satire account @gerejapalsu can be seen from the highlights in the about us section. This account is created for a private circle. This account is not talking about saving souls. Compare with the churches of today whether the churches that put forward the great financial miracles have done so. It is easier to put out a fire in terms of correcting the wrong doctrine or warning someone about the danger of fire. ${ }^{31}$ That part is in the purpose of the account @ gerejapalsu which can be interpreted as satire language style is this account is not an account that looks holy like a big church that emphasizes the salvation of

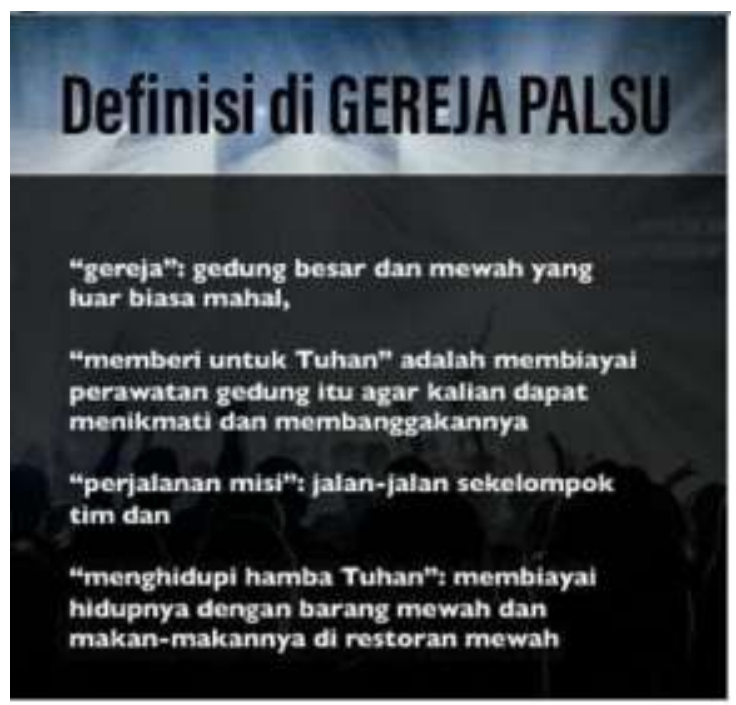

souls but in teaching teaches only blessings. This account focuses on everyone being able to better understand the true doctrine or teachings so that they can avoid the dangers of fire (false doctrines). The @gerejapalsu account consistently uses the satire language style to continually educate its followers.

The satire@gerejapalsu account provides some education about some of the deviations that have occurred in the churches that promote a luxury lifestyle. The input provided by the @ gerejapalsu account is usually related to the doctrines of deviant teachings, the lifestyle of church leaders, the concept of worship that is nonChrist centered, and some deviations that certain churches today do. Some examples of satire language styles used are:

\section{Definition in the "Gereja Palsu"}

Church: A large and luxurious building that is extraordinarily expensive

Giving for God : Building maintenance fund so that the congregation can enjoy and be proud

Mission Trip: traveling as a group of teams

support God's servants: his bills with luxury goods and food at a fancy restaurant

Fig. 1. Form satire to define churches that have deviated

30 @gerejapalsu, "Profil," last modified the translation 2019, accessed January 20, 2020, https://www.instagram.com/gerejapalsu/.

31 @ gerejapalsu, “About Us.” 
The post above is one form of satire of the @ gerejapalsu account to satirize the churches in the current deviant. The post clearly shows some of the mistakes that have been made by the Church today. Some of them are the "Church" must be a large and luxurious building, although in fact the House of God must be good, but if this is the main focus then it is a form of deviation from the Church today. Second, "giving to God" by paying for the care of the church to be proud of which means that all members of the church are blessed because of the offerings given. "Mission Trips", missionary journeys become a journey of a team with the main agenda for travel but are wrapped spiritually. so it is contradictory that offerings that are supposed to be for God's glory actually become luxury goods owned by shepherds. The languages above are satire languages intended to educate congregants and churches that have the habit as above. The meaning can be interpreted as follows: first, the Church does have to pay attention to the building but does not have to give focus on the luxury of the building. Secondly, the offerings should be for God's work but instead only become a pride to maintain a luxurious building. Third, missionary travel is used only for tourism, this should be used to reach people who do not know the gospel at all. Fourth, offerings should be managed transparently for the expansion of the Kingdom of God not only for luxury items belonging to God's servants. Satire language above provides education for all believers to be able to provide input on deviations that have been intentionally or unintentionally done by the Churches of God at present.

Various responses were given to posts from the satire @ gerejapalsu account. Some of these responses include supporting satire posts. Some netizens feel very educated because of the satire posts that have been published by the @gerejapalsu account. Citizens who have a positive response appreciate the work of the@gerejapalsu account and the uniqueness of these, citizens are also challenged to examine the true truth of the deviations that have been made by the Churches of God at present. Some citizens were very grateful because in the end, this opened their horizons of knowledge that so far there had been some distortions and the Lord Jesus was no longer the center of the Church. Some of them are also aware of the various policies of God's servants who seem not good enough, such as buying luxury items at very expensive prices, often preaching about blessings and their relationship with tithes and others. Citizens who support this account feel that this account is very educational. The other side is negative opinions from some followers of the satire@gerejapalsu account. Those who give negative responses due to inconsistencies with the facts and what they experience separately. Some of them even invited the admin debate and considered the satire language style given as an insult or a mockery of certain Christians. Many also those who attacked this account and reported that this account is not an account that is for education. They are trying to discredit posts from the @ gerejapalsu account. The satire that given by@gerejapalsu account is marked as the sarcasm account that attacks the denomination, church, or person of a servant of God. These things that make some citizens do not give respect to this account.

Citizens who disagree often provide responses to marginalize the satire account@gerejapalsu. They assume that the owner of this account is a person who is full of bitterness. They gave stupid debates to bring down the account @ gerejapalsu. Followers of the target satire@gerejapalsu account also often attack the account. They appealed that the account@gerejapalsu should not judge God's churches at this time. Some actions 
taken by the admin @gerejapalsu is to block and break friendships from those who attack the account. Various suggestions for criticism are ultimately responded to with the eyes of those who do not want to accept these criticisms. In the end, the @gerejapalsu account was opposed by various groups as a result of satire posts directed against these circles.

\section{RESULTS AND DISCUSSION}

This section describes the link between holistic pneumatology and the satire Instagram account @gerejapalsu. The data that has been displayed is then carried out the reduction process. The reduction is done by taking big points from the data that has been displayed. The reduced data is presented in the following table:

\begin{tabular}{|c|c|c|}
\hline $\begin{array}{l}\text { Holistic } \quad \text { Pneumatology } \\
\text { Anabaptist Mission and } \\
\text { Charismatic Pentecostal }\end{array}$ & $\begin{array}{l}\text { Satire Account@gerejapalsu } \\
\text { Movement }\end{array}$ & $\begin{array}{l}\text { Withdrawal of } \quad \text { Data } \\
\text { Interpretation }\end{array}$ \\
\hline $\begin{array}{l}\text { The mission movement is } \\
\text { based on the Church's } \\
\text { motivation to renew the } \\
\text { previously established } \\
\text { churches from corrupt } \\
\text { practices. }\end{array}$ & $\begin{array}{l}\text { Use the satire style of } \\
\text { language to warn churches of } \\
\text { the present that have } \\
\text { diverged. }\end{array}$ & $\begin{array}{l}\text { Both have similarities with } \\
\text { motivation to continually } \\
\text { renew the Lord's Church } \\
\text { from deviant practices. }\end{array}$ \\
\hline $\begin{array}{l}\text { Holistic pneumatology } \\
\text { spawned a movement with } \\
\text { the aim of continually } \\
\text { spreading the good news for } \\
\text { the world as practiced by the } \\
\text { anabaptist and pentecostal- } \\
\text { charismatic traditions. }\end{array}$ & $\begin{array}{l}\text { This account focuses on } \\
\text { everyone being able to better } \\
\text { understand the true doctrine } \\
\text { or teachings so that they can } \\
\text { avoid the dangers of fire } \\
\text { (false doctrines) }\end{array}$ & $\begin{array}{l}\text { Both have the same in } \\
\text { continually guarding God's } \\
\text { people in the call of mission } \\
\text { and avoiding them from } \\
\text { inappropriate doctrines. }\end{array}$ \\
\hline $\begin{array}{l}\text { Has been marginalized by the } \\
\text { Churches and is considered } \\
\text { heresy. }\end{array}$ & $\begin{array}{l}\text { Has been marginalized by } \\
\text { churches that feel "affected" } \\
\text { by the satire account } \\
\text { @gerejapalsu account so that } \\
\text { eventually this account is } \\
\text { considered an account that is } \\
\text { related to a Church } \\
\text { denomination }\end{array}$ & $\begin{array}{l}\text { Both have the same thing that } \\
\text { is equally marginalized by } \\
\text { the previous established } \\
\text { churches. }\end{array}$ \\
\hline
\end{tabular}

Table 1. Interactive analysis

The results of the interpretation of data interpretation then carried out a description of the relationship between holistic pumatumatology on the satire instagram account of @gerejapalsu.

\section{The Social Media Phenomenon of Satire Account @gerejapalsu In The Movement of Holistic Pneumatology}

The research process produced an overview of the relationship between holistic pneumatology and the phenomenon of social media satire account @ gerejapalsu. Research reveals that there is a link between these two phenomena. The link is described as follows:

First, both have similarities with motivation to continually renew the Church of God from deviant practices. The holistic pneumatology mission of the anabaptist and charismatic pentecostal traditions with the satire account 
@gerejapalsu has the same purpose. Anabaptists renewed the stagnation of the reformed and Luther churches which had stagnated due to their struggle with the Catholic Church. Pentaskotal-charismatic renewed from the stagnation of the church due to the modernization period in which reason is the main reference at that time. The satire account @gerejapalsu has renewed the churches of God from the deviations that have been made. The role of the Holy Spirit pushes for these actors to contribute to the churches that have been established previously. This is because the Holy Spirit always wants to make God's churches not only silent but continue to work for God. Another thing is to encourage the churches also not to fall protracted in the deviations that have been done. Based on this both from anabaptistpentecostal-charismatic and satire accounts is a holistic pneumatology movement to renew the churches of God in the present.

Secondly, Both have the same in continually guarding God's people in the call of mission and avoiding them from inappropriate doctrines. The work of the Holy Spirit works on the anabaptistpentecostal-charismatic and satire Instagram account@gerejapalsu counterfeit trying not to bring the church to wrong practices and doctrines. Most of the wrong practices and doctrines of a church are due to changes in the purpose of the church that is not focused on carrying out God's call on this world. Another thing is because of the love of money. This makes God's churches often experience conflicts and there are irregularities in their teachings. The @gerejap Fake account seeks to return the church of God to its calling and focus the church on Christ. This is also done by the Anabaptist tradition and the pentecostal-charismatic tradition. The role of the Holy Spirit helps to continue to defend the church so that it does not deviate and does not produce doctrines that are contrary to the Bible.
Holistic pneumatology keeps the Churches of God faithful in their mission calls.

Thirdly, Both have the same thing that is equally marginalized by the previously established churches. The role of the Holy Spirit often has an impact on principals that they are ridiculed, ostracized, and considered heretics. Such is the case with the anabaptist, pentecostalcharismatic, and satire account movements. The various discourses undertaken by the movement have had a mixed effect on believers, one of which is those who disagree with the movement. Anabaptist and Pentecostal-charismatic traditions give an illustration of the struggle of their group, which first of all they are often faced with persecution, punishment, and persecution because they are considered as heretical sects. The satire Instagram @gerejapalsu account also gets the same treatment. Some groups who disagree with the movement of this satire account provide bullying, ridicule, slur, and driver debate on the @gerejapalsu account. The @gerejapalsu account is also often considered heretical and is considered an account led by people who have bitterness about a Church denomination. These things are intended to turn off the characters from the satire @ gerejapalsu account. In contrast to the events of persecution experienced by both anabaptist, pentecostal-charismatic, and satire accounts @gerejapalsu, the Holy Spirit continues to accompany. This can be seen from the followers who remain loyal to follow them. They are also imparted to continually renew themselves so that God's Church today does not fall into sin. Based on these things the role of the Holy Spirit is holistically very visible in this movement. Despite having many opponents but there is still an inclusion from God.

This study reveals that the account of satire@gerejapalsu has a link with the holistic pneumatology movement. The 
basic principle that underlies this movement is to renew the church together from inappropriate practices that are developing in the churches in their respective times..

\section{CONCLUSIONS RECOMMENDATIONS}

AND

This research results in a link between the holistic pneumatology of the anabaptist movement and the pentecostalcharismatic with the movement of the satire@gerejapalsu account. This study illustrates this linkage with three interrelations, namely: First, both have similarities with the motivation to continually renew the Church of God from deviant practices. secondly, Both have the same in continually guarding God's people in the call of mission and avoiding them from inappropriate doctrines. Third, both have in common that they are equally marginalized by the previously established churches. This research concludes the holistic role of the Holy Spirit in the movement of anabaptists, pentecostalcharismatics, and satire Instagram account @ gerejapalsu.

The suggestion from this research is the need for further research on citizens' responses in the quantitative form to the satisfaction and effectiveness of satire accounts in providing renewal for God's churches today.

\section{REFERENCE}

@gerejapalsu. “About Us.” Accessed January 22, 2020.

https://www.instagram.com/stories/hi ghlights/17914047550292920/.

"Definisi Gereja Palsu." Last modified 2019. Accessed January 23, 2020.

https://www.instagram.com/p/B6X2U oghcwgHbDsfyH5AazqOP3UmAA9 TW9MJAo0/.
. "Profil." Last modified 2019.

Accessed January 20, 2020.

https://www.instagram.com/gerejapal $\mathrm{su} /$.

_. "Rules." Last modified 2019.

Accessed January 22, 2020.

https://www.instagram.com/stories/hi ghlights/18026363224126762/.

Adhi, Eka Adhi, and Heru Kristanto.

"Korupsi Dalam Pelayanan Gereja :

Analisis Potensi Penyimpangan Dan

Pengendalian Internal." Integritas 3, no. 2 (2017): 105-136.

Adimihardja, Kusnaka. Metode Penelitian Sosial : Suatu Teknik Penelitian

Bidang Kesejahteraan Sosial Dan Ilmu Sosial Lainnya. Edited by Jan Budhi. Edisi ke-8. Bandung: PT Remaja Rosdakarya Offset, 2011.

Daniel Sutoyo. "Pneumatologi Lukas: Pemberdayaan Pelayanan Kristen." Jurnal Antusias 4, no. 7 (2015): 1-33. http://www.sttintheos.ac.id/ejournal/index.php/antusias/article/vie $\mathrm{w} / 1 / 1$.

Fleming, Jody B. "Holistic Pneumatology in Mission." Anabaptist Witness 1 (2017): 11-29.

Gultom, Junifrius. "PNEUMATOLOGI AMOS YONG DAN REFLEKSI MISIOLOGI (Perspektif Pentakosta/Kharismatik Indonesia)." Jurnal Antusias 2, no. 4 (2013).

Haryono, T, and Daniel Fajar Panuntun. "Andil Pemuridan Kontekstual Yesus Kepada Petrus Yakobus Dan Yohanes Terhadap Keterbukaan Konseling Mahasiswa Pada Masa Kini." Gamaliel : Teologi dan praktika 1, no. 1 (2019): 12-25. " "Model Gaya Hidup Nazir Sebagai Refleksi Gaya Hidup Hedon 
Pengkotbah Pada Zaman Milenial.” Evangelikal: Jurnal Teologi Injili dan Pembinaan Warga Jemaat 3, no. 2 (2019): 174-184.

Irfan, Moh. Fatih. "ANALISIS GAYA BAHASA SINDIRAN DALAM AKUN TWITTER USTADZ TENGKU ZULKARNAIN." UNIVERSITAS MUHAMMADIYAH MALANG, 2019.

Lumintang, Stevri Indra Danik Astuti Lumintang. Theologia Penelitian Dan Penelitian Theologis ScienceAscience Serta Metodologinya. Jakarta: Geneva Insani Indonesia, 2016.

Miles, M. B., and A. M. Huberman. Qualitative Data Analysis: A Sourcebook of New Methods. California: SAGE publications, 1982.

Muzaki, Ahmad. "SATIRE POLITIK PILPRES 2019 PADA AKUN INSTAGRAM." UNIVERSITAS MUHAMMADIYAH MALANG, 2019.

Nnamdi Okoye, Herbert, and Linda Chika Nwaigwe. "The Impact of Globalization to Business and the World Economy." International Journal of Business and Management Review 3, no. 5 (2015): 17-32. www.eajournals.org.

Nugroho, Fibry Jati. “Gereja Dan Kemiskinan: Diskursus Peran Gereja Di Tengah Kemiskinan." Evangelikal : Jurnal Teologi Injili dan Pembinaan Warga Jemaat. 3, no. 1 (2019).

Panuntun, Daniel Fajar, and Eunike Paramita. "HUBUNGAN PEMBELAJARAN ALKITAB TERHADAP NILAI-NILAI (
KELOMPOK TUMBUH BERSAMA KONTEKSTUAL )." Gamaliel :

Teologi dan praktika 1, no. 2 (2019): 104-115.

Saputri, Ardilla, and Risana Rachmatan. "Religiusitas Dengan Gaya Hidup Hedonisme: Sebuah Gambaran Pada Mahasiswa Universitas Syiah Kuala." Jurnal Psikologi 12, no. 2 (2017): 59.

Setyawati, Naris Eka. "A Satire on Social Class and Gender in Victorian Society Reflected Through the Main Characters in J.M. Barrie's The Tweleve Pound Look." Sanata Dharma, 2009.

Siahaan, Harls Evan. "DUNAMIS ( Jurnal Teologi Dan Pendidikan Kristiani ) Karakteristik Pentakostalisme Menurut Kisah Para Rasul." DUNAMIS (Jurnal Teologi dan Pendidikan Kristiani) 2, no. 1 (2017): 12-28.

Theodorus, Frans, and Peniel C D Maiaweng. "Pneumatologi Berdasarkan Yohanes 14 : 16-17 Dan Implikasinya Bagi Kehidupan Orang Percaya." Repository Skripsi Online 1, no. 4 (2018): 16-17.

Untari, Dewi. GAYA BAHASA DALAM MEME DI MEDIA SOSIAL. Jakarta, 2018.

Wadipalapa, Rendy Pahrun. "Meme Culture \& Komedi-Satire Politik: Kontestasi Pemilihan Presiden Dalam Media Baru." Jurnal ILMU KOMUNIKASI 12, no. 1 (2015): 117.

Wright, R. Consumer Behaviour. Hampshire: Cengage learning EMA, 2006.

Yuliati, and Kezia Yemima. "MODEL PEMURIDAN KONSELING BAGI 


\begin{abstract}
ALUMNUS PERGURUAN TINGGI
LULUSAN BARU (FRESH

GRADUATE) YANG

MENGINGKARI PANGGILAN

PELAYANAN" 1, no. 1 (2019): 26-
\end{abstract}

40. 